\title{
Excitatory Amino Acid Receptor Antagonist in Murine Motoneuron Disease (The Wobbler Mouse)
}

\author{
Charles Krieger, Thomas L. Perry*, Shirley Hansen, Hiroshi Mitsumoto and Tage Honoré
}

\begin{abstract}
Recent evidence has suggested a potential role for involvement of excitatory amino acids (EAA) in the pathogenesis of the neuron loss in motoneuron diseases. We have examined the ability of an antagonist of N-methyl-Daspartate (NMDA) receptors to halt or retard the progression of neurological symptoms in a murine form of motoneuron disease. The wobbler mouse is an autosomal recessive mutant which develops progressive neurological symptoms secondary to motoneuron loss. Treatment of wobbler mice with the NMDA receptor antagonist $(+)-5$-methyl-10,11dihydro-5H-dibenzo(a,d)cyclohepten-5, 10-imine maleate (MK-801) did not retard neurological deterioration as assessed by a semiquantitive clinical scale. We conclude that NMDA receptor activation is probably not involved in the pathogenesis of motoneuron loss in the wobbler mouse.
\end{abstract}

RÉSUMÉ: Antagoniste des recépteurs d'acides aminés excitateurs dans la maladie murine du neurone moteur. Des données récentes suggèrent que les acides aminés excitateurs (AAE) ont possiblement un rôle à jouer dans la pathogenèse de la perte neuronale dans les maladies du neurone moteur. Nous avons examiné la capacité d'un antagoniste des récepteurs du $\mathrm{N}$-méthyl-D-aspartate (NMDA) d'arrêter ou de retarder la progression des symptômes neurologiques dans une forme murine de maladie du neurone moteur. La souris "wobbler" est une lignée mutante autosomale récessive qui développe des symptômes neurologiques progressifs secondaires à une perte de neurones moteurs. Le traitement de souris "wobbler" avec un antagoniste du récepteur du NMDA, la maléate de (+)-5-méthyl-10,11-dihydro-5H-dibenzo(a,d)cyclohepten-5,10-imine (MK-801) n'a pas retardé la déterioration neurologique selon une échelle d'évaluation clinique semi-quantitative. Nous concluons que l'activation du récepteur du NMDA n'est probablement pas impliquée dans la pathogenèse de la perte de neurones moteurs chez la souris "wobbler".

Can.J. Neurol.Sci. 1992; 19:462-465

The cause of the motoneuron loss in most neurodegenerative disorders is unknown. Excitatory neurotoxic compounds have been suggested as possible causes for the motoneuron losses observed in sporadic amyotrophic lateral sclerosis (ALS), ${ }^{1.2 .3}$ as well as in the ALS-parkinsonism-dementia complex observed in the Mariana Islands. ${ }^{4}$ Excitatory amino acid (EAA) receptors are present on motoneurons both in vivo ${ }^{5}$ and in vitro, ${ }^{6}$ and exposure to EAA such as domoic acid can lead to motoneuron dysfunction in man. ${ }^{7}$

In patients with sporadic ALS, concentrations of glutamic acid have been reported to be elevated in fasting plasma,' and levels of glutamate, aspartate and $\mathrm{N}$-acetyl-aspartate have been reported as increased in cerebrospinal fluid (CSF). ${ }^{3}$ Some of these findings have not been confirmed. ${ }^{8}$ Studies of autopsied brains and spinal cords from patients dying with ALS have demonstrated decreased contents of glutamate, aspartate, $\mathrm{N}$ acetyl-aspartate and $\mathrm{N}$-acetyl-aspartylglutamate in many regions of the nervous system, which might be secondary to neuroexcitotoxic damage ${ }^{1.9 .10}$ Autoradiographic studies of EAA receptors have shown decreased binding of NMDA receptor ligands in both the dorsal and ventral horns of cervical and thoracic spinal cord segments from patients who have died with ALS, compared to controls." This reduction in NMDA receptors in ALS could potentially arise from an excitotoxic mechanism. In the event that neuroexcitotoxic compounds are involved in the pathogenesis of ALS, administration of antagonist acting at EAA receptors might arrest or slow the clinical course of ALS. Presumably to be optimally effective, EAA receptor antagonists would have to be given early in the course of the disease before motoneuron death becomes extensive.

The wobbler mouse ( $w r / w r)$, is an autosomal recessive mutant in inbred C57BL/Fa mice which develops degeneration of motoneurons within the brainstem and spinal cord and has been proposed as an animal model for ALS. 12 The wobbler

From the Division of Neurology (C.K.), Department of Medicine, Department of Pharmacology and Therapeutics (T.L.P., S.H.), The University of British Columbia, Vancouver; Department of Neurology, The Cleveland Clinic Foundation, Cleveland (H.M.); Novo Nordisk A/S, CNS Division, Sydmarken 5, Soeborg, Denmark (T.H.)

Received March 3, 1992. Accepted May 6, 1992

* Deceased

Reprint requests to: C. Krieger, Division of Neurology, Department of Medicine, 2211 Wesbrook Mall, Vancouver, British Columbia, Canada V6T IW5 
mouse is clinically normal at birth and indistinguishable from normal littermates. Beginning at 3-4 weeks of age, it gains weight less rapidly than normal littermates and develops progressive neurological symptoms including tremor, a gait disorder, forepaw weakness and atrophy, as well as extraocular muscle involvement from about 4-12 weeks of age. ${ }^{13}$ The disease progression is variable. However, by 12-16 weeks of age some wobbler mice die as a result of the severe muscle weakness, while in other mice the disease progression may slow down or stop. Heterozygous littermates are phenotypically normal.

Glutamate and aspartate contents are decreased in spinal cords from wobbler mice compared to controls, however, these reductions are much less than those observed in patients dying with ALS. ${ }^{14}$ As tissue glutamate and aspartate contents primarily reflect levels in the intracellular compartment, the reduced spinal cord contents of glutamate and aspartate in wobbler mice could be due to increased release at EAA from nerve terminals, resulting in decreased tissue levels and potentially excitotoxic damage to motoneurons.

We attempted to halt or retard the progression of the neurological deterioration in wobbler mice by daily injections of $(+)$ 5-methyl-10,11-dihydro-5H-dibenzo(a,d)cyclohepten-5, 10imine maleate (MK-801), a phencyclidine-like compound which is a non-competitive antagonist of EAA at the N-methyl-Daspartate (NMDA) receptor. ${ }^{15}$ This potent NMDA receptor antagonist was used from the earliest possible preclinical stage of the disease, in doses believed to be effective for EAA receptor blockade. ${ }^{16}$ Portions of this work have been presented in abstract form. ${ }^{17}$

\section{Materials and Methods}

Litters containing wobbler mice and unaffected littermates were produced using clinically normal heterozygous $(+/ w r)$ mouse breeding pairs obtained from the Cleveland Clinic Foundation colony. Litters were clinically examined for wobbler mice having motoneuron disease, and a grading of the disease progression was made based on a disability scale modified from previous studies. ${ }^{18}$

Walking - 0 - normal; 1 - trembling (tremor without a gait disturbance); 2 - wobbling (gait disturbance); 3 - curled paw walking; 4 - jaw walking, no use of front paws.

Paw condition - 0 - normal; 1 - atrophy; 2 - curled digits; 3 curled wrists; 4 - forelimb flexed to chest.

Eye condition - 0 - normal; 1 - attached exudate; 2 - narrowed palpebral fissure (unilateral); 3 - narrowed palpebral fissures (bilateral); 4 - clogged eye (single or both).

Wobbler mice were distinguished from unaffected littermates by the insidious development of neurological deterioration and lack of weight gain. In the initial stages of the disorder the symptoms were subtle. However, as the disorder progressed, the features became unambiguous and the earliest abnormalities of individual wobbler mice could be identified retrospectively.

Within 4 days of birth, offspring of breeding pairs were weighed daily and given daily subcutaneous injections of MK$801(0.25 \mathrm{mg} / \mathrm{kg}$ or $0.5 \mathrm{mg} / \mathrm{kg})$ in saline. Control animals comprised a group of 5 wobbler mice having a disability score of greater than zero on the above scale and which were given intraperitoneal injections of saline 6 times per week for 9 weeks. Saline injections were begun in these animals as soon as the motoneuron disease was clinically confirmed at 3-4 weeks of age, and were continued until animals were 12-13 weeks of age. The experimenters were not blinded to the drug being given.

Treatments with MK-801 were continued for 4-6 weeks, until it became clear that some mice did not express the wobbler phenotype. This was usually apparent when the mice reached a weight of greater than $20 \mathrm{~g}$ and were clinically normal (disability scale of zero). Wobbler mice (those having delayed weight gain and neurological disability) were treated for a total of 11-14 weeks from birth. Statistical comparisons were made between groups using a repeated measures analysis of variance with Holm's correction. ${ }^{19}$

\section{Results}

Figure I shows that the mean body weights of wobbler mice were less than the mean weights of unaffected littermates (filled squares), regardless of whether they were treated with MK-801 (filled triangles), or saline (open squares). Differences in weight between wobbler mice and littermates became apparent around 3-4 weeks after birth, although some wobblers did not have clinical evidence of motoneuron disease until several days later. Although the mean weight of wobbler mice increased with age, the rate of increase was much less than in normal littermates. A statistically significant difference $(p<0.05 \%)$ was observed between the mean body weights of saline-injected wobbler mice $(\mathrm{n}=5)$ and those wobbler mice receiving MK-801 [at 0.25 $\mathrm{mg} / \mathrm{kg}(\mathrm{n}=6)$ or $0.5 \mathrm{mg} / \mathrm{kg}(\mathrm{n}=2)$ ] at week 11 only. No significant differences were observed between groups at other times between week 4 and week 12 .

Mean clinical disability scores were determined in each treatment group for the 3 parameters evaluated (walking, paw condition and eye involvement). Unaffected littermates of wobbler mice had no evidence of neurological disease regardless of their age or treatment. At no time did we observe a clinically normal mouse develop symptoms of neurological disease at cessation of treatment. Wobbler mice exhibited continued progression of their neurological disease regardless of whether they were treated with MK-801, or saline. Table I shows in matrix table form that little difference was observed in the mean paw disability score between MK-801 or saline-treated wobbler mice over 12 weeks. The number of data points is less in week 12 than in week 11 as treatment was stopped in some animals before week 12. Statistical comparisons between groups did not demonstrate differences between the walking, paw and eye disability scores of MK-801 and saline-treated mice between weeks 4 to 12 . Clinical assessment immediately after injections of MK-801 or saline or within one-half hour post-injection never demonstrated any clinical improvement.

At no time did we detect a mouse which had a weight intermediate between the wobbler mice and the unaffected littermates, which would have suggested a possible clinical benefit from NMDA receptor antagonism. Similarly, we never observed a mouse having a weight comparable to the control group after 3-4 weeks which later developed neurological deterioration.

To insure that the maximum possible antagonism of NMDA type EAA receptors was reached, we initially used $\mathrm{MK}-801$ at a dose of $0.5 \mathrm{mg} / \mathrm{kg} / \mathrm{day}$ and began treatment at birth. Use of this 


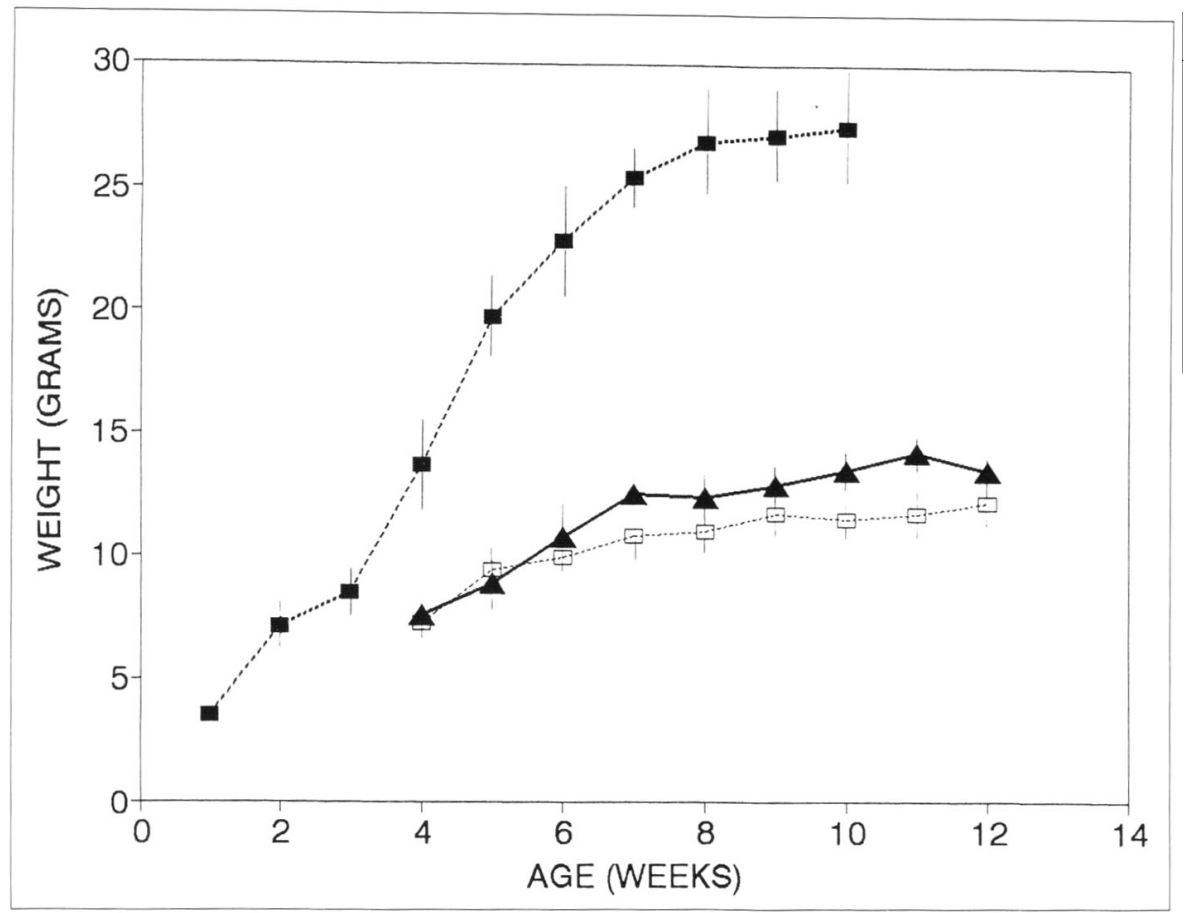

Figure I - Mean body weights of control mice (unaffected littermates: filled squares) and wobbler mice treated with $M K \cdot 801$ (filled triangles) or saline (open squares). Vertical lines indicate standard deviations (I S.D.) for each point. Mean weights of control mice are derived from greater than 10 animals for each data point: $M K-801-8$ animals for each data point. except for 4-week point. $n=7$ and 12-week point. $n=6$, saline -5 animals, except for 4-week point $n=4$, and 12 -week point $n=3$

\section{Table 1: Paw Condition}

\begin{tabular}{|c|c|c|c|c|c|c|}
\hline Week & Treatment & Normal & \multicolumn{2}{|c|}{ Number of Animals Affected } & Curled wrist & Forelimb flexed to chest \\
\hline 3 & $\begin{array}{l}\text { Saline }(n=5) \\
\text { MK- } 801(n=8)\end{array}$ & $\begin{array}{l}5 \\
8\end{array}$ & & & & \\
\hline 4 & $\begin{array}{l}\text { Saline } \\
\text { MK-801 }\end{array}$ & $\begin{array}{l}3 \\
6\end{array}$ & $\begin{array}{l}2 \\
1\end{array}$ & 1 & & \\
\hline 5 & $\begin{array}{l}\text { Saline } \\
\text { MK-801 }\end{array}$ & $\begin{array}{l}1 \\
5\end{array}$ & $\begin{array}{l}2 \\
1\end{array}$ & $\begin{array}{l}2 \\
2\end{array}$ & & \\
\hline 6 & $\begin{array}{l}\text { Saline } \\
\text { MK-801 }\end{array}$ & 4 & $\begin{array}{l}1 \\
1\end{array}$ & $\begin{array}{l}4 \\
3\end{array}$ & & \\
\hline 7 & $\begin{array}{l}\text { Saline } \\
\text { MK-801 }\end{array}$ & 2 & $\begin{array}{l}1 \\
1\end{array}$ & $\begin{array}{l}1 \\
5\end{array}$ & 3 & \\
\hline 8 & $\begin{array}{l}\text { Saline } \\
\text { MK-801 }\end{array}$ & 2 & 1 & 3 & $\begin{array}{l}5 \\
2\end{array}$ & \\
\hline 11 & $\begin{array}{l}\text { Saline } \\
\text { MK-801 }\end{array}$ & & & 1 & $\begin{array}{l}1 \\
4\end{array}$ & $\begin{array}{l}4 \\
3\end{array}$ \\
\hline 12 & $\begin{array}{l}\text { Saline }(n=3) \\
\text { MK-801 }(n=7)\end{array}$ & & & 1 & $\begin{array}{l}1 \\
3\end{array}$ & $\begin{array}{l}2 \\
3\end{array}$ \\
\hline
\end{tabular}

Frequency of paw condition disability score in wobbler mice given saline or MK-801 treatment - Frequency of paw condition disability score (see text) between weeks 3 to 12 after birth for animals given treatment as shown, ' $n$ '-beside treatment indicates number of animals treated each week. Number of animals in the 12-week group are as shown. 
dose led to illness in many mouse pups, manifested by lethargy, feeble movements, weight loss and death within several days of treatment. Of 43 mice treated using this dose, only 8 survived, 2 of which were wobbler mice. MK-801 at a dose of $0.25 \mathrm{mg} / \mathrm{kg} / \mathrm{day}$ produced less morbidity or mortality in the mice. Of 46 mice treated with this dose, 27 survived. Of the total 35 surviving mice injected with MK-801, 8 (22.8\%) exhibited the homozygous ( $w r / w r)$ phenotype. This frequency of $w r / w r$ homozygotes, although less than $25 \%$ expected for an autosomal recessive trait, is similar to previously published values. ${ }^{13}$

\section{Discussion}

The wobbler mouse has been proposed as an animal model of ALS, as it develops progressive motoneuron degeneration without clinical evidence of abnormalities in sensory pathways. ${ }^{12}$ To test the hypothesis that the motoneuron destruction in wobbler mice is associated with involvement of NMDA receptors, we used an antagonist of EAA actions on the NMDA receptor. In spite of early treatment of mouse litters with MK801 , the expected number of homozygous wobbler mice was observed and their clinical course appeared identical to that of saline-treated animals. Furthermore, we never observed a clinically normal mouse develop symptoms of neurological disease at cessation of treatment, which might have suggested that the wobbler phenotype had been altered by drug treatment. Treatment was begun prior to the development of clinical symptoms, as soon after birth as was possible. Because of the toxicity of MK-801, this meant beginning treatment several days after birth.

Treatment with MK-801 in doses of $0.5 \mathrm{mg} / \mathrm{kg} / \mathrm{day}$ several days after birth produced considerable number of deaths of young mice, usually preceded by lethargy and relative immobility, and these animals were often neglected by their mothers. MK-80I in doses of $0.25 \mathrm{mg} / \mathrm{kg} /$ day produced considerably less morbidity and mortality. CDI mice aged 2 months or more were able to tolerate doses of MK-801 of $1 \mathrm{mg} / \mathrm{kg} /$ day although a dosage of $2 \mathrm{mg} / \mathrm{kg} /$ day produced weight loss as well as severe ataxia, excitement and falling, lasting 3 hours after drug administration. ${ }^{16}$ We never observed these symptoms in any of the animals studied here. As in previous studies, no lasting behavioural effects were observed in MK-801 treated mice over the 12 week period. ${ }^{16}$

The present results indicate that the underlying pathogenic process responsible for motoneuron destruction in the wobbler mouse probably does not involve mediation by NMDA receptor activation. The relevance of these observations for the pathophysiology of ALS is unclear. The neurological disease in wobbler mice is only partially similar to human ALS. ${ }^{12.13}$ However, as low doses of MK-801 do not produce lasting behavioural changes in mice and would be expected to block NMDA receptors in humans, they might be of potential value in the treatment of human neurological diseases associated with NMDA excitotoxicity.

\section{ACKNOWLEDGEMENTS}

We thank Debbie Cannon, Dr. Michael Schulzer, E. Mak and M. Frouws for assistance. MK-801 was generously supplied by Dr. P.S. Anderson; Merck, Sharp \& Dohme Research Laboratories, West Point, PA. This work was supported by the Medical Research Council of Canada and the British Columbia Health Research Foundation.

\section{REFERENCES}

1. Plaitakis A, Caroscio JT. Abnormal glutamate metabolism in amyotrophic lateral sclerosis. Ann Neurol 1987; 22: 575-579.

2. Plaitakis A, Constantakakis E, Smith J. The neuroexcitotoxic amino acids glutamate and aspartate are altered in the spinal cord and brain in amyotrophic lateral sclerosis. Ann Neurol 1988: 24: 446.449 .

3. Rothstein JD, Tsai G, Kuncl RW, et al. Abnormal excitatory amino acid metabolism in amyotrophic lateral sclerosis. Am Neurol 1990; 28: 18-25.

4. Spencer PS, Nunn PB, Hugon J, et al. Guam amyotrophic lateral sclerosis-parkinsonism-dementia linked to a plant excitant neurotoxin. Science 1987; 237: 517-522.

5. Biscoe TJ, Evans RH, Headley PM, et al. Structure-activity relations of excitatory amino acids on frog and rat spinal neurons. $\mathrm{Br} J$ Pharmacol 1976; 58: 373-382.

6. O'Brien RJ, Fischbach GD. Characterization of excitatory amino acid receptors expressed by embryonic chick motoneurons in vitro. J Neurosci 1986; 6: 3275-3283.

7. Teitelbaum JS, Zatorre RJ, Carpenter S, et al. Neurologic sequelae of domoic acid intoxication due to the ingestion of contaminated mussels. N Engl J Med 1990; 322: 1781-1787.

8. Perry TL, Krieger C. Hansen S, et al. Amyotrophic lateral sclerosis: amino acid levels in plasma and cerebrospinal fluid. Ann Neurol 1990; 28: 12-17.

9. Perry TL, Hansen S, Jones K. Brain glutamate deficiency in amyotrophic lateral sclerosis. Neurology 1987; 37: 1845-1848.

10. Tsai G, Stauch-Slusher B, Sim L, et al. Reductions in acidic amino acids and $\mathrm{N}$-acetylaspartylglutamate in amyotrophic lateral sclerosis CNS. Brain Res 1991; 556: 151-156.

11. Allaoua $\mathrm{H}$, Chaudieu I, Krieger C, et al. Alterations in spinal cord excitatory amino acids receptors in amyotrophic lateral sclerosis patients. Brain Res 1992; 579: 169-172.

12. Duchen LW. Motor neuron diseases in man and animals. Invest Cell Pathol 1978; 1: 249-262.

13. Duchen LW, Strich SJ, Falconer DS. An hereditary motor neurone disease with progressive denervation of muscle in the mouse: the mutant "wobbler". J Neurol Neurosurg Psychiatry 1968; 31: 535-542.

14. Krieger C, Perry TL, Hansen S, et al. The wobbler mouse: amino acid contents in brain and spinal cord. Brain Res 1991; 551: 142-144.

15. Wong EHF, Kemp JA, Priestley T, et al. The anticonvulsant MK801 is a potent N-methyl-D-asparate antagonist. Proc Natl Acad Sci USA 1986; 83: 7104-7108.

16. Perry TL, Bergeron C, Biro AJ, et al. B-N-Methylamino-L-alanine: chronic oral administration is not neurotoxic to mice. J Neurol Sci 1989; 94: 173-180.

17. Krieger C, Perry TL, Hansen S, et al. Excitatory amino acid receptor antagonists in murine motoneuron disease. Can J Neurol Sci 1991: 18: 261 .

18. Kozachuk WE, Mitsumoto H, Salanga VD, et al. Thyrotropin-releasing hormone (TRH) in murine motor neuron disease (the wobbler mouse). J Neurol Sci 1987; 78: 253-260.

19. Holland BS, Copenhaver MD. Improved Bonferroni-type multiple testing procedures. Psych Bull 1988; 104: 145-149. 